\title{
電子デバイスにおける接着接合 Adhesive Bonding in Electron Devices
}

\author{
池上 皓 三* \\ Kozo IKEGAMI
}

\section{1. まえがき}

情報化社会の発展, 機器の知能化の進展につれて, 半 導体デバイスに代表される電子デバイスの使用範囲は飛 䍜的に拡大している。このような応用範囲の拡大につれ て, 電子デバイスへの信頼性への要求がますます高まる 一方, 電子デバイス自体の高機能化, 高集積化む極めて 早い速度で進行している。

電子デパイスには, セラミック, 金属, プラスチック の材料が使用され，それらの材料の相互接合によって， 電子デバイスの機能が発現される。電子デバイスは異種 材料によって構成される複合微小接合構造体であり, 異 種材料の接合はほとんど接着接合されている。電子デバ イスの信頼性は, デバイス内部の異種材料間の接合の信 頼性によって決まるといっても過言では無い。このよう なデバイスでは, 内部の非常に小さな損傷, たとえばデ バイス構成材料のわずかなき裂, 構成材料間の微小なは く離などが, デバイス機能に致命的な影暨を与え, さら にそのデバイスが使用されているシステム機能の停止を 引き起こす場合もある。

電子デバイス内部の材料間の接合の力学的な因子を評 価し，その損傷を防ぐことが，高信頼性デバイス実現の 鍵となってきている。ここでは電子デバイスの製造過程 や使用時に現れるいくつかの接合問題をとりあげ, デバ イス健全性との関連について述べ。

\section{2. 電子デバイスの製造過程}

電子デバイスの製造過程は, シリコンやガリュウム砒

\footnotetext{
$*$ 東京電機大学工学部機械工学科

東京都千代田区神田錦町 2-2 \% 101-8457

Tokyo Denki University

2-2 Kanda-Nishiki-cho, Chiyoda-ku, Tokyo, Japan (平成 15 年度日本接着学会年次大会特別講演)
}

素のウエハ上に電子回路を形成し, 電子機能を発現する チップを製造する工程と, チップをパッケイジしてデバ イスに仕上げる工程に大きくわけることが出来る。前者 の工程はさらに多結晶シリコンやガリュウム砒素を溶融 して単結晶インゴットを製造し，そのインゴットを薄層 のウエハに切断する工程と, ウエハの上に回路を形成す る工程よりなる。後者の工程は回路を形成されたウエハ から 1 個ずつチップ切断し基板に接合した後, チップの 電極と外部電極を接続する工程と，基板に接合されたチッ プを樹脂などで封止する工程よりなる。

図 1) は面実装された電子デバイスの内部構造の概略 の一例で, シリコンチップがパッドに接着椄合されたの

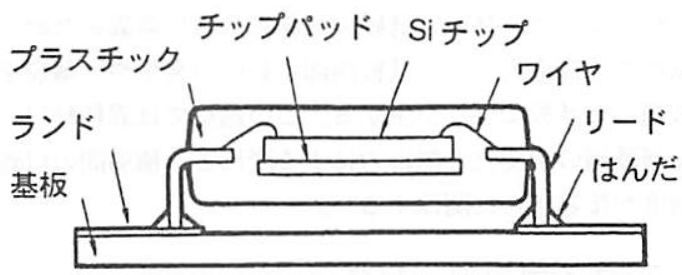

図 1 面実装された電子デパイス

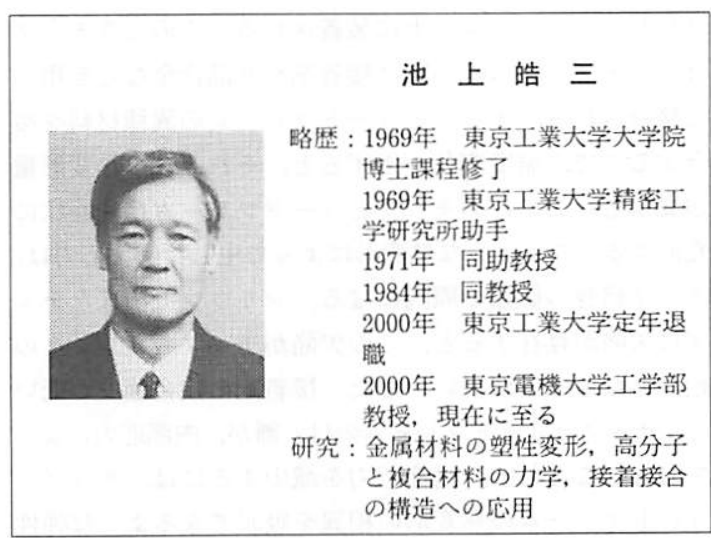


ち、チップの電極とリードフレームがワイヤによって接 続され, チップ, パッド, ワイヤとリードフレームの一 部分を, プラスチック材料で封止したものである。力学 的モデルとしての電子デバイスは, セラミック，金属， プラスチックの三種の材料よりなる微小接合部をむつ薄 層積層体といえる。

\section{3. デバイス用インゴットとウエハ}

電子デバイスの機能を発現するチップは，まず多結晶 体シリコンやガリュウム砒素のような材料を溶融して, 単結晶のインゴットを作り, そのインゴットを薄層に切 断しウエハに加工する。このときインゴットに内部応力 があると, 薄層に切断したときに, 内部応力が解放され てウエハに反りが生じ変形する。チップの回路パターン は, ウエハのうえに塗布した感光剤に, 回路パターンを 繰り返し露光して形成してゆくので, ウェハに反りがあ ると回路パターンの不整合が生じ，チップの歩留まりに 大きく影響する2)。この過程ではウエ八を研摩するため の固定作業が, 接着接合に関係する。研摩時の固定方法 がウエハの反りに影響する。

\section{4. 回路形成}

デバイスの回路はウエハ上に回路パターンを蒸着して 形成してゆく。この過程は異種材料の薄膜を積層してゆ く工程である。たとえば，シリコン基板上に薄膜 $\left(\mathrm{SiO}_{2}\right)$ を蒸着する過程では, 薄膜の固化過程時の体積 変化やシリコン基板と薄膜の熱膨張係数の差異のため, 基板に内部応力が生じ基板内部に転位の発生や, 薄膜を 被覆した基板に反りが生ずる。この過程では異種材料の 薄層積層の相変化之熱応力による変形と, 積層間の付着 強度が接着接合に関係する ${ }^{3,4)}$ 。

\section{5. ダイボンディング}

回路を形成されたウエハからチップを切断し，そのチッ プがリードフレームの上に装着される。このときチップ はリードフレームとの間に接着剤や共晶合金などを用い て接合される。チップとリードフレームの異種材料を接 合するので, 温度変化が生ずると, それぞれの熱変形量 が異なる。このためチップとリードフレームは曲面状に 変形する。このような熱変形によって生じた内部応力は, チップ自身の破損の原因になる。シリコンで出来たチッ プに欠陌が存在すると、この欠宿がチップのクラックの 始点となることが多い。また，接着㓮の接合強度が低い と, チップとリードフレームのはく離が, 内部応力によっ て引き起こされる。内部応力を滅少するには, チップと リードフレームの熱変形の相異を吸収できるような弾性
に富み，かつ接合強度の高い接着剮が必要である。この 過程は接着接合そのもの過程で, 接着剂の選択がダイボ ンディングの信頼性に大きな影響を及ぼす5.66。

\section{6. 電極接続}

チップを電子デバイスとして実際に機能させるために, チップの電極が外部電極に接続される。金やアルミニウ ムの細線を用いて, 電極を接続するワイヤボンディング, チップの電極と基板の電極を細線を用いずに直接接続す るフリップチップ、テープ上に形成された配線パターン を用いて接続するテープキャリアがある。電極接合はど の方法も接着接合そのものである。

\section{1 ワイヤボンディング}

細線によって電極接続を行う場合, 細線の先端を溶融 し球状にして接続するボールボンディングと, 細線の先 端をそのまま接続するウェッジボンディングがある。接 続に用いる細線の直径は数 $10 \mu \mathrm{m}$ であるので, 接合さ れる面積はきわめて小さい。電極接合に不良が発生する と電子デバイスの機能に致命的な影響を与える。このた め微小接合面積で信頼性の高い接合を確保しなければな らず, 接合部の強度がきわめて重要である7.8)。

\section{2 フリップチップ}

チップの電極をはんだをつけた基板の電極に, それぞ れ位置合わせし仮圧着した後, はんだを溶かして電極同 士を一括接合する方法である。チップと基板の熱膨張係 数は一般には異なるので, はんだづけ過程での加熱によっ て生ずる熱変形は，チップと基板で異なる。はんだづけ 後室温に戻ったとき, それぞれの熱変形の差によって, はんだ接合部にせん断荷重が作用する。この荷重により はんだ接合部のはんだボールにひずみが発生する。フリッ プチップで接合されたデバイスが, 絽返し加熱冷却を受 けると，はんだ接合部に繰返しひずみが作用することに なり，はんだ接合部の疲労破壊を招くことがある。した がって, チップと基板の熱的性質を出来るだけ近づけ, はんだ接合部に加わるひずみを出来るだけ小さくする必 要がある゙ ${ }^{9} 10 \%$

\section{3 テープキャリヤ}

プラスチックフィルムに接続パターンをエッチングし たリードフレームと, チップの電極端子 (バンプ) を熱 圧着する。電極端子は異種材料の積層構造をしている。 熱圧着時の加熱により，電極を構成する異種材料層に熱 応力が発生する。この熱応力と加熱による応力が重畳し て, 電極や基板の破損を引き起こすことがある。電極の 材料構成は電気的な機能の必要性から变えることが困難 であるので, 電極の形状を変えて, 熱圧着時の応力を軽 隇する方法が試みられている11.12)。 


\section{7. デバイスの封止}

外部電極と接続されたチップを, 衛撃, 摩擦, 振動, 熱などの外部環境から保護することが必要である。これ にはチップを金属やセラミックのキャップ内に密閉する 気密封止と，チップを樹脂でコーティングする樹脂封止 などがある。コストや生産性の点から樹脂封止が多く用 いられている。この過程においてあ接着機能が重要な役 割をむっている。

封止された樹脂が硬化するとき，樹脂の力学性質に 変化が生じ，その体積も収縮する。このために封止樹脂 の硬化時に樹脂に内部応力が発生する。さらに封止樹脂 とチップ, チップパッド, リードフレームの間の熱膨張 係数の違いにより, 樹脂封止されたチップに温度变化 が生ずると，樹脂だけでなく，チップ，チップパッド， リードフレームにも内部応力が発生する。これらの内部 応力が, 樹脂とリードフレームの接合部のはく離を引き 起こしたり, 封止機能そのものの破損を起こす場合もあ る。

樹脂でチップをコーティングし十分な封止勃果をあげ るためには，樹脂とチップ，チップが接着されている基 板とリードフレームとの高い接着性が必要である。接着 が悪いとリードフレームと封止樹脂の接合部ではく離が 起こり, はく離部から水分が浸入し内部の配線の腐食な どを引き起こす。

封止樹脂の内部応力を軽減し, 接着性を高めことは, 樹脂封止の信頼性にきわめて重要である13.14, 15, 16,17, 18)。

\section{8. 電子デバイスにおける接着接合}

これまで述べてきたように，電子デバイスの構造は殆 ど接着接合によって成り立っている。これら接着接合に 関係する力学的な問題の共通因子を要約する之,

（1）相変化時の物性 （2）異種材料間の熱残留応力

(3) 薄層微小構造

となる。以下これらのいくつかについての研究結果を述 ベる。

\section{1 相変化時の熱硬化性樹脂の物性}

電子デバイスに使用される熱硬化性樹脂は, 液体から 固体に相変化する過程で体積収縮すると同時に，その力 学的性質も時間に依存して複雑に变化する。また，硬化 時には樹脂内部で発熱が起こり, 樹脂内部の温度は不均 一になり，樹脂の物性値も複雑に変化する。したがって 樹脂の硬化時の特性を把握するためには, 相変化過程て の体積変化之物性変化を調べる必要がある。

熱硬化性樹脂として変性エポキシ樹脂を用いて，2重 円筒法により樹脂に硬化剂を加えて，樹脂の温度を (a)

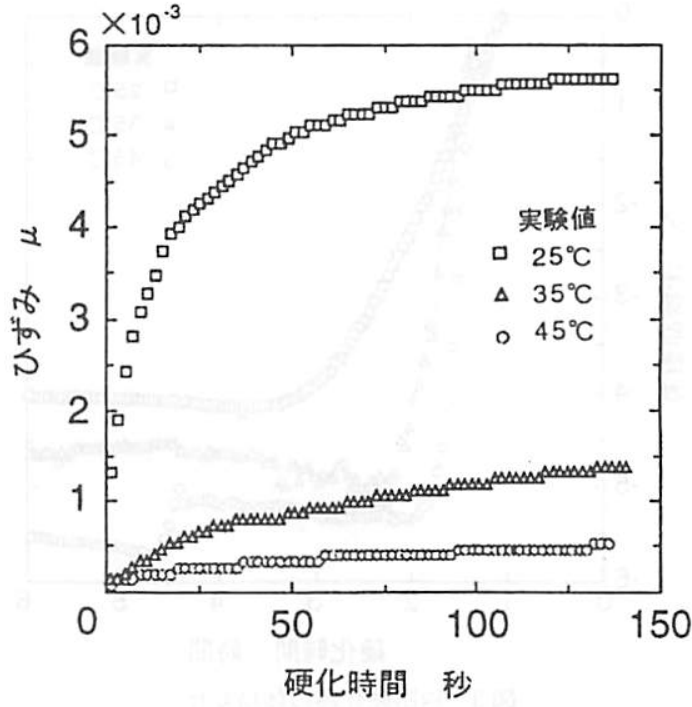

図 2 樹脂硬化時の粘弾性特性

25 度，（b） 35 度，（c） 45 度の条件で硬化させ,その ときのクリープコンプライアンスの測定結果が図 $2^{19)}$ で ある。これは硬化剂を樹脂に加えて，3.5 時間後に測定 した結果である。クリープひずみの大きさは樹脂の温度 によって異なり，温度が低いほど大きくなっている。 このクリープひずみは温度だけでなく，硬化剤を加え た後の経過時間にも関係し，硬化剂を加えた初期の段 階ではクリープひずみは小さく，時間の経過とともにク リープひずみはおおおきくな粘弾性特性が顕著になる。 さらに時間が経過し硬化終了に近くなると，樹脂のクリー プひずみは小さくなり，ほぼ弾性体と見なせるようにな る。

樹脂の硬化時の体積収縮をディラトメータを用いて測 定した結果が図 $3^{19)}$ である。硬化㓮を加えたのち, 硬化 が進行するときの体積変化を時間に対して示してある。 測定温度はクリープひずみを測定した時と同じ温度条件 である。樹脂の温度が (b) 35 度や (c) 45 度の場合には, 体積収縮が急速に生じ，ほぼ 2 時間から 2.5 時間後に体 積収縮が終わっているが，樹脂の温度が (a) 25 度の場 合にはほぼ 3.5 時間後に収縮が終わっており, 硬化収縮 速度が樹脂温度に大きく影響を受けている。また硬化収 縮量は樹脂温度が高くなるほど大きくなっている。

これらの物性変化を 3 要素の粘弾性モデルで定式化し， アルミ板之樹脂の 2 層モデルの樹脂硬化過程の変形を解 析し，実験と比較したのが図 $4^{19)}$ である。このモデルは 長さ $100 \mathrm{~mm}$, 幅 $20 \mathrm{~mm}$, 厚さ $1 \mathrm{~mm}$ のアルミ合金板上に, $10 \mathrm{~mm}$ 厚さに樹脂を硬化させたものである。図に示す 結果では図中の 2 層はりの中央（A 点）のひずみを測 


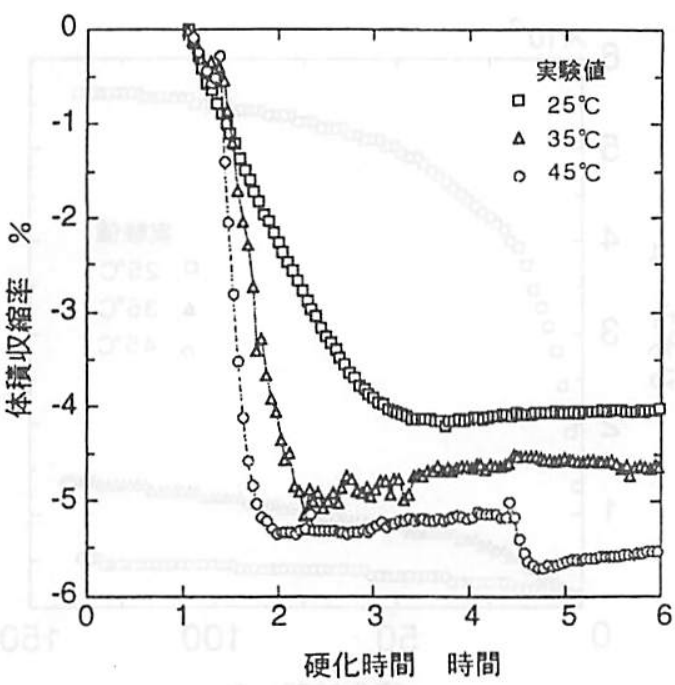

図 3 樹脂硬化時の体積変化

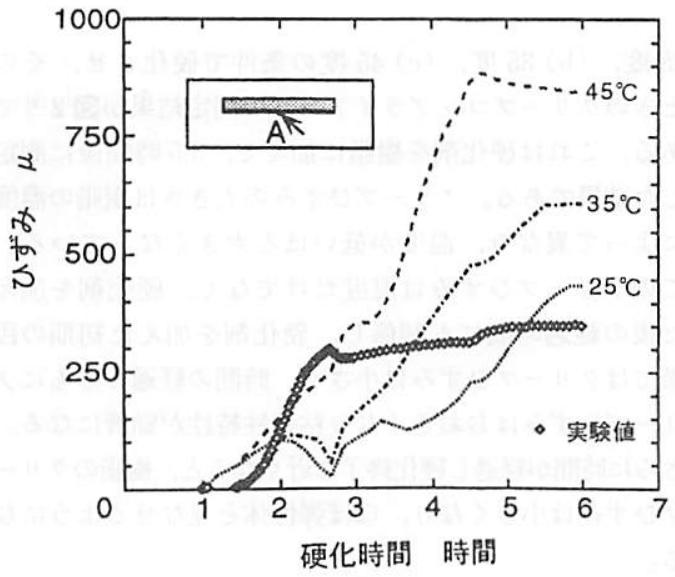

図 42 層板の樹脂硬化時の残留ひずみ

定した結果と粘弾性モデルによる計算結果を比較して いる。実験の温度条件は 35 度である。計算結果は (a) 25 度, (b) 35 度, (c) 45 度の場合について示してある。 ひずみが時間とともに增加し， 2 層モデルが変形してい ることがわかる。ひずみの増加の傾向は計算結果と実験 結果はほぼ同じであるが，ひずみの大きさについては, 計算結果と実験結果の一致はよくない。これは 2 層モデ ル内では温度分布が一様と仮定しているが, 実際は自己 発熱のため温度が一様でなかったためと考えられる。

\section{2 異種樻層部の熱応力}

電子デパイスはセラミック, 金属, 樹脂の薄層の積層 複合構造になっているので, 熱変化を受けるとそれぞれ の材料が互いに拘束しながら変形するので, その内部で 熱応力が発生する。この熱応力により積層材料の界面で

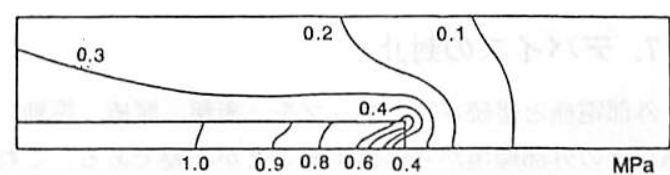

(a) $170^{\circ} \mathrm{C}$

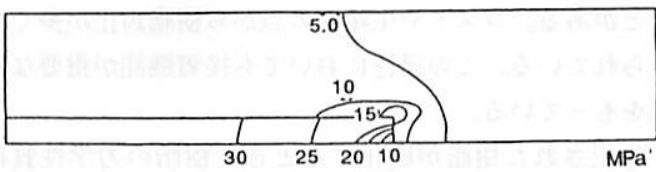

(b) $100^{\circ} \mathrm{C}$

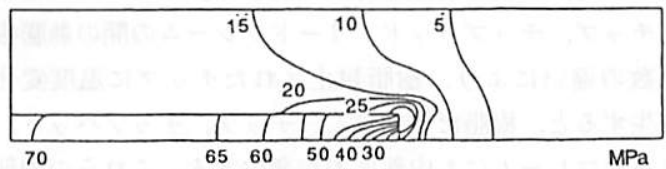

(c) $20^{\circ} \mathrm{C}$

図 5 樹脂硬化後の冷却過程の残留応力

のはく離あるいは積層材料そのものの破損が生じ, 電子 デバイスの機能停止を引き起こす。異種材料からなる複 合構造の熱応力の状態を把握しておくことは, デバイス の健全性の評価に重要である。

内部に異種材料のある硬化後の樹脂の熱応力の状態を 調べるために，デバイスのパッケイジ樹脂の硬化後の樹 脂の粘弹性の力学的性質を, クリープコンプライアンス で測定した。種々の温度で測定したクリープコンプライ アンスは測定温度により異なり，その温度依存性が大き い。さらに硬化樹脂の線膨張係数を測定して熱変形の特 性を調べた。これらの結果をもとに，樹脂の熱変形時の 椣成関係を粘弾性モデルで定式化し，樹脂と金属の複合 構造体の熱応力を解析した。解析モデルは厚さ $10 \mathrm{~mm}$, 一辺の長さが $50 \mathrm{~mm}$ の正方形の樹脂の中央に, 厚さ $2 \mathrm{~mm}$, 一辺の長さが $30 \mathrm{~mm}$ の炭素鋼の板を埋め込んだもので ある。モデルにあたえた温度条件は 170 度で 5 時間の加 熱後, 室温まで冷却する過程である。図 $5^{20)}$ の (a) (b) （c）はそれぞれ 170 度で加熱時，100 度まで冷却時， 20 度まで冷却時の熱残留応力の状態を，相当応力の等高線 で示したものである。応力分布はモデルの $1 / 4$ の部分 について描かれている。左下の板状の部分が埋め込まれ た炭素綱板の $1 / 4$ である。樹脂の残留応力は樹脂を粘 弾性体としているが, 炭素綱板の残留応力は炭素綱板を 弾性体として, 解析している。樹脂を高温で硬化させて いるときには, 残留応力は小さいが, 温度が下がるにつ れて残留応力が大きくなっているのがわかる。また樹脂 では炭素網板の角で大きな残留応力が発生し, 炭素網板 


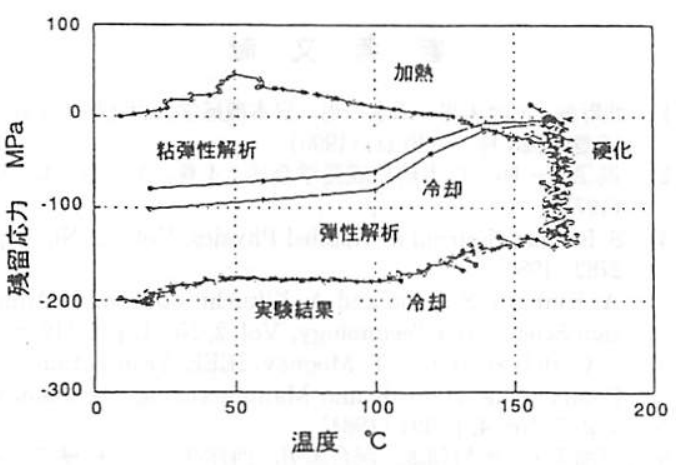

図 6 樹脂硬化時の残留応力

では中央で大きな応力が生じている。

このパッケイジ用樹脂の硬化冷却時の内部応力を解析 モデルと同様の試料を作り, 内部に埋め込んだ炭素綱板 にストレインゲージを貼り, 解析条件と同じ温度条件で 硬化冷却したときの内部応力の測定結果が図 $6^{3)}$ である。 図には測定結果のほかに，樹脂を弾性体と粘弾性体と仮 定したときの結果す示してある。樹脂の加熱を始め約 90 分で温度が 170 度に達するまで, 樹脂は未硬化であ るため, 応力はほとんど生じない。樹脂の硬化が始まる と圧縮汒力が生じ, 硬化終了時にはほぼ-130MPaの 圧縮応力が生じている。さらに泠却過程では圧縮応力 はほぼ 100 度まで增加し，100 度以下では増加するむの のその増加量は小さい。最終的に 20 度では残留応力は -200MPa までになる。解析結果と测定結果を比較する と, 両者の傾向はほぼ一致しているが, 定量的には一致 していない。この原因の一つとして, 樹脂内部の温度の 不均一分布が考えられる。

\section{3 微小接合部の強度}

電子デバイスの高密度化, 高集積化が進むにつれて, 接合部は極めて微細化され, 極小面積で十分な接続機能 を果たすことが要求され, 接合部の力学的条件は厳しく なっている。接合部の接合強度を評価することは，デバ イスの信頼性の保証に重要である。デバイスの接合部に は接合された部分の異種材料間の熱変形の差異により, せん断だけでなく曲げや引張, 圧縮の荷重を受けること があるので，接合部に複合荷重を加えてその強度特性を 調べる必要がある。

図 $7^{21)}$ はデバイス接合に用いられる BGA をモデルに した接合部試験片である。直径 $1 \mathrm{~mm}$ のはんだボールを 使用して，配線パターンを焼き付けた基板を接合したす のである。はんだボールで接合した基板に垂直応力を加 えた引張試験を行ったときの, 応力とひずみの関係が 図 $8^{21)}$ である。図の (a) と（b）には，それぞれ試験温 度が 24 度と 100 度の場合が示されている。どちらの温

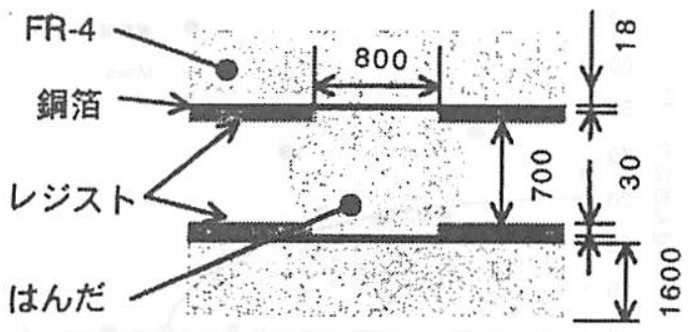

単位 $\mu \mathrm{m}$

図 7 はんだ接合の試験片

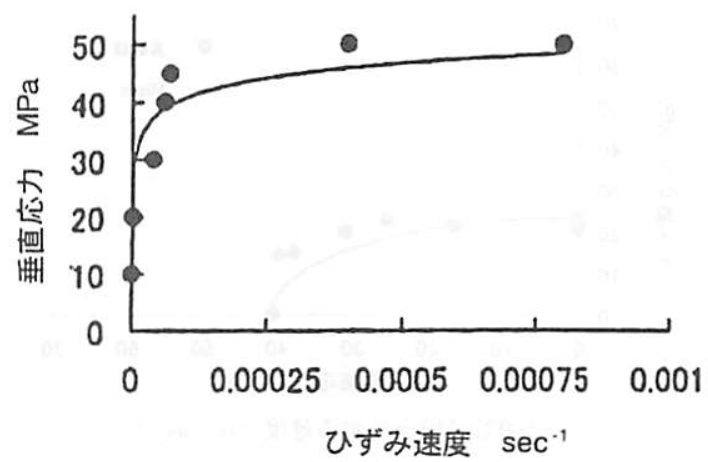

(a) $24^{\circ} \mathrm{C}$

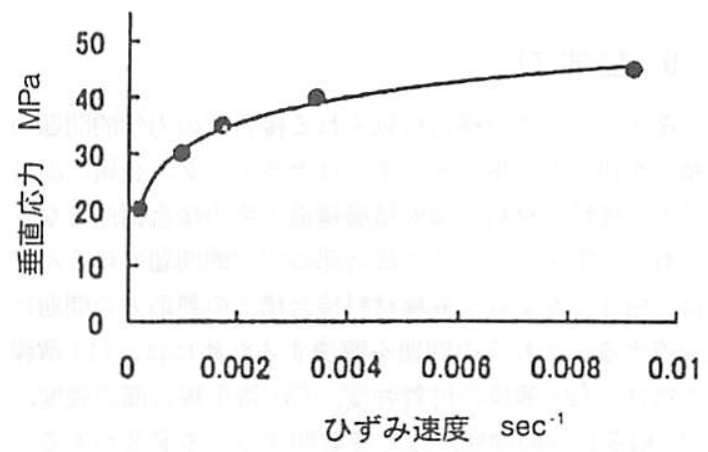

(b) $100^{\circ} \mathrm{C}$

図 8 はんだ接合部の変形特性

度条件でも大きく塑性変形しているが，100 度の場合の ほうが塑性变形量は多い。また加工硬化率は 24 度の場 合のほうが大きい。図 $9^{21)}$ は引張応力とせん断応力の複 合応力を加えた時の強度である。図の（a）と（b)には, それぞれ試験温度が 24 度と 100 度の場合が示されてい る。図中の実線は引張強度をもとに Mises の条件で計 算した複合応力のもとでの強度である。24 度では実験 值のばらつきがやや大きいが, Misesの条件よりやや大 きくなっている。また 100 度では実験值のばらつきも少 なく, Misesの条件にほぼ一致している。 


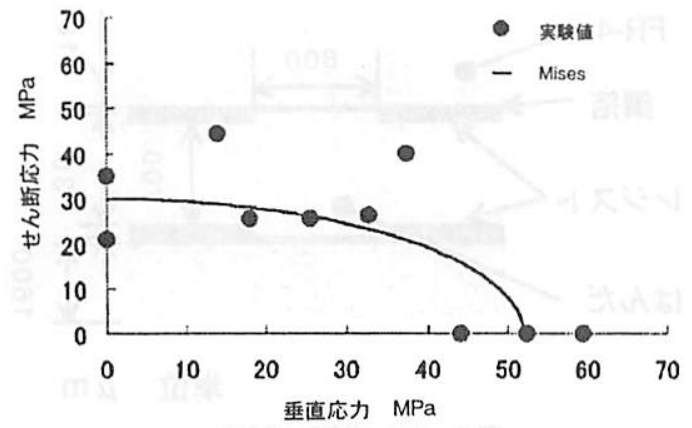

（a） $24^{\circ} \mathrm{C}$ （相当ひずみ速度 $0.0005 \mathrm{sec}^{-1}$ )

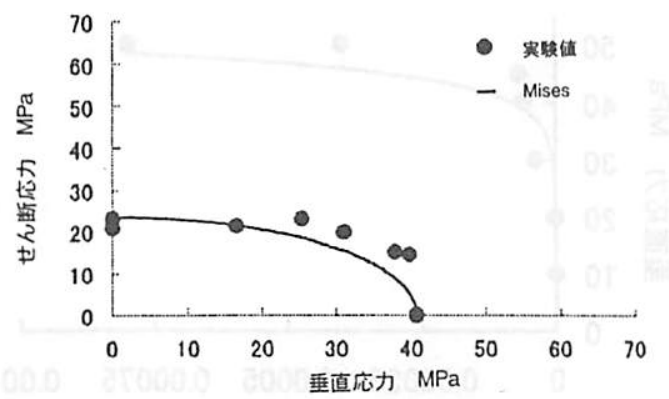

(b) $100^{\circ} \mathrm{C}$ （相当ひずみ速度 $0.005 \mathrm{sec}^{-1}$ )

図 9 はんだ接合部の複合応力下での強度

\section{9. むすび}

電子デバイスの構造に見られる接合部の力学的問題の 概略を述べた。電子デバイスはセラミック，金属，高分 子の 3 種類の材料の薄層積層構造と微小接合構造となっ ており, 電子デバイスの接合部の力学的問題のほとんど は, 相変化を受ける異種材料接合構造の熱応力の問題に 㷌着する。これらの問題を解決するためには，(1) 薄膜 の物性, (2) 薄膜の付着強度, (3) 微小接合部の強度, （4）相変化時の物性, などを解明するする必要がある。 電子デバイスの信頼性は異種材料の接合部の力学的特性 に大きく関係しているといえる。なお，本報告は日本接 着学会第 41 回年次大会での特別講演の内容に加筆した あのである。

\section{参 考 文 献}

1）北野誠，河合末男，清水一男：日本機械学会論文集， A 編： 56 卷, 525 号, 1140 頁 (1990)

2）高須新一郎：日本結晶成長学会誌：4 巻, $1 / 2$ 号, 121 頁 (1977)

3) S. Isomae: Journal of Applied Physics, Vol. 52, No. 4, p. $2782(1980)$

4) A. Kinbara, S. Baba and A. Kikuchi: Journal of Adhesion Science and Technology, Vol. 2, No. 1, p. 1 (1988)

5) J. C. Bolger and C. T. Mooney: IEEE Transactions of Components, Hybrids and Manufacturing Technology, Vol. 7. No. 4, p. 394 (1984)

6）三浦英生, 西村朝雄, 河合末男, 西邦彦：日本機械学会論 文集, $\mathrm{A}$ 編, 53 巻, 493 号, 1826 頁 (1987)

7）柏原稳，中山了, 鈴木政男：日本電信電話公社 電気通信 研究所, 研究実用化報告, 17 巻, 6 号, 1123 頁 (1968)

8) J. Onuki, M. Suwa, M. Koizumi and T. Iizuka: IEEE Transactions of Components, Hybrids and Manufacturing Technology, Vol. 10. No. 2, p. 242 (1987)

9) L. S. Goldman: IBM Journal of Research Development, Vol. 13, No. 5, p. 251 (1969)

10）佐藤了平, 大島宗夫, 黄田和夫, 石一郎：日本金属学会会 報, 23 巻, 12 号, 1004 頁 (1984)

11) J. W. Kanz, G. W. Braun and R. F. Unger: IEEE Transactions of Components, Hybrids and Manufacturing Technology, Vol. 2. No. 3, p. 301 (1979)

12）山口武則, 橋本慎, 水谷卓之: 日本機械学会誌, 84 巻, 755 号, 1070 頁 (1983)

13) K. M. Liechti: Experimental Mechanics,Vol. 25, No. 9, p. 226 (1985)

14) K. Miyake, H.Suzuki and S. Yamamoto: IEEE Transactions on Reliability, Vol. 34, No. 5, p. 402 (1985)

15）坂田注司, 服部俊雄, 初田俊雄：日本機械学会埨文集, A 編 : 53 巻, 495 号, 2151 頁 (1987)

16）服部敏雄, 坂田荘司, 初田俊雄, 村上元：日本機械学会論 文集, $\mathrm{A}$ 編： 54 巻, 499 号, 597 頁 (1988)

17）西村朝雄, 広㖽閥, 田中直敬：日本機械学会論文集, $\mathrm{A}$ 編： 59 巻, 559 号, 620 頁 (1993)

18）田中直敬, 西村朝雄：日本機械学会論文集, $\mathrm{A}$ 編：60 巻, 577 号, 1992 頁 (1994)

19）松井広明, 池上皓三：日本機械学会論文集, $\mathrm{A}$ 編：62 卷, 596 号, 993 頁 (1996)

20）河田裕志, 池上皓三：日本機械学会論文集, A 編：56 巻, 532 号, 2471 頁 (1990)

21）桐生昌祥, 吉岡成典, 池上皓三：第 17 回エレクトロニク 又実装学術講演大会講演論文集, 63 頁 (2002) 